Original article

\title{
The antifungal action of three South African honeys on Candida albicans
}

\author{
Frans THEUNISSEN ${ }^{\mathrm{a} *}$, Sias GROBLER ${ }^{\mathrm{a}}$, Itzhak GEDALIA ${ }^{\mathrm{b}}$ \\ ${ }^{\text {a }}$ Faculty of Dentistry, University of Stellenbosch, Private Bag X1, Tygerberg 7505, South Africa \\ b Oral Biology, Faculty of Dentistry, The Hebrew University Hadassah School of Dental medicine, \\ Jerusalem, Israel
}

(Received 3 April 2000; revised 4 October 2000; accepted 17 May 2001)

\begin{abstract}
The purpose of this study was to investigate the antifungal action of three single samples of South African honey (wasbessie, bluegum and fynbos) against Candida albicans. Various dilutions of honey were prepared in brain-heart infusion broth, ranging in concentration from 0 to $25 \%$ (w/w). This was inoculated with C. albicans, while a hypertonic sugar solution served as a control. All dilutions were incubated overnight and the optical density was measured in a spectrophotometer. The sugar control and the 3 honey samples stimulated the growth of $C$. albicans and was optimal between $2.5 \%$ and $5 \%$. Increased honey concentrations resulted in reduced growth of $C$. albicans; wasbessie honey at a concentration of $25 \%$ demonstrated $29.4 \%$ inhibition on the growth of $C$. albicans, while the control, bluegum and fynbos honey produced only partial inhibition.
\end{abstract}

honey / antifungal action / antimicrobial action / oral micro flora / Candida albicans

\section{INTRODUCTION}

Honey has been used as a medicine since ancient times in many cultures. Aristotle (ca. $350 \mathrm{BC}$ ) referred to the use of honey in medicine (Smith and Ross, 1910) Since early times, common uses of honey included treatment of ulcers, bedsores and infections resulting from burns and wounds (Goulart, 1979; Armon, 1980). Honey has also been found to be effective against organisms iso- lated from urinary tract infections (Ibrahim, 1981) and in the treatment of infantile gastro-enteritis (Haffejee and Moosa, 1985).

The first study on the antimicrobial effects of honey was reported by Van Ketel in 1892 and is mentioned by Dustmann (1979). Since then, various other studies have been published on this subject (Allen et al., 1991; Basson et al., 1994; Dustmann, 1979; Ibrahim, 1981; Molan, 1992; Revathy et al., 1980). A great deal of work has been

* Correspondence and reprints

E-mail: fst@ maties.sun.ac.za 
done in an attempt to identify the antimicrobial agents in honey and the range of organisms susceptible to this antimicrobial action. The word "inhibine" was introduced to describe these antimicrobial agents and this term is still used today (Dold et al., 1937). One review article lists 64 different bacterial and 13 fungal species on which antimicrobial action has been tested (Molan, 1992).

Staphylococcus aureus is an organism that has been included in most comparative studies and has been found to be one of the most sensitive to the antibacterial action of honey. This is of medical importance, since $S$. aureus has become a major cause of wound infections and septicaemia in hospitals (Efem, 1988).

In patients with impaired immunity, neonates or the elderly, $C$. albicans can cause oral candidiasis, also known as thrush. A survey of the literature shows that very little work has been done on the antimicrobial effects of honey in the oral environment. Basson et al. (1994) found that bacterial growth of seven species in the oral Streptococcus group was uninhibited by bluegum honey (Eucalyptus cladocalyx) at concentrations below $21 \%$ (v/v). However, the growth of Streptococcus anginosus and Streptococcus oralis were inhibited at $17 \%$ and $12 \%$ respectively.

Sela et al. (1998) found, in an in vivo study, that the initial microhardness of the surface of human enamel decreased significantly after consumption of a teaspoonful of honey in subjects with a normal salivary flow, while the microhardness did not change in patients with a dry mouth condition. Grobler et al. (1994) showed through scanning electron microscopy and microhardness tests that their honey sample did not dissolve human enamel in vitro, despite the low $\mathrm{pH}$ value (4.2) of the sample. This result could only be partially attributed to the calcium, phosphorus and fluoride levels in honey; the elements normally associated with the solubility of enamel and dentine. It is well known that enamel dissolves easily in a solution with such a low $\mathrm{pH}$ value (Grobler, Jenkins and Kotze, 1985; Grobler et al., 1989).

The major antimicrobial factors in honey may be summarised as follows:

Osmotic effect. Eighty two percent $(\mathrm{w} / \mathrm{w})$ of honey is a mixture of various carbohydrates, such as glucose, fructose, maltose and sucrose, resulting in a very low water content (Root, 1983; National Honey Board, 1988). This condition is inhibitory to the growth of bacteria, since water is removed from the bacterial cell. Fungi are generally much more tolerant than bacteria to the high osmotic effect and do not cause spoilage of honey when the water content is below 17\% (Molan, 1992).

Acidity. The $\mathrm{pH}$ of honey is between 3.2 and 4.5 , mainly due to the presence of gluconic acid (White, 1975). This is considerably lower than the optimum $\mathrm{pH}$ of 7.2 to 7.4 required for the growth of most bacteria.

Hydrogen peroxide $\left(\mathrm{H}_{2} \mathrm{O}_{2}\right)$. This is sometimes found in diluted honey and is a product of the oxidation of glucose by the enzyme glucose oxidase. This enzyme is inactivated by exposure to sunlight (White et al., 1963). The addition of catalase to honey results in the breakdown of $\mathrm{H}_{2} \mathrm{O}_{2}$.

Other. This includes plant-derived substances termed flavonoids (Havsteen, 1983), the most important member being pinocembrin (Molan, 1992). Lysozymes and volatile substances found in plants may also be included here.

The objective of this study was to examine the antifungal action of single samples of honey against $C$. albicans, a common inhabitant in the oral cavity of normal healthy humans.

\section{MATERIALS AND METHODS}

\subsection{Honey samples}

A single randomly-selected sample of 3 different types of honey, commonly found 
in the Western Cape region of South Africa, were collected from hives by apiarists. After removal of the honey from the combs, the 3 samples were delivered to the authors. The honey was stored, in the dark and at room temperature, in $500 \mathrm{ml}$ plastic jars until required for use. No artificial additives or diluents were added to the honey and they were not subjected to any excessive heating. Honey types were identified and considered to be monofloral in two cases by the apiarists themselves. They were from the floral types bluegum (Eucalyptus cladoca$l y x$ ) and wasbessie (Myrica cordifolia). Fynbos is a mixture of many heather shrubs, but mainly Erica species.

All samples were examined for sterility and irradiated by gamma rays at a dosage of 20 kilograys for 10 hours (Molan and Allen, 1996). Because honey is very viscous, it was more convenient and practical to prepare dilutions by weight and not by volume. All honey dilutions referred to in this study are on a weight by weight (w/w) basis. The specific gravity of the bluegum, fynbos and wasbessie honey was investigated and found to be 1.455, 1.469 and 1.440 respectively.

All honey samples were weighed in $100 \mathrm{ml}$ plastic containers before varying amounts of sterile water and $25 \mathrm{ml}$ of double strength brain heart infusion broth (BHI broth code CM225, Oxoid, Basingstoke, England) were added. The final volume was $50 \mathrm{ml}$ and dilutions ranged from 0 to $25 \%$ (w/w). The initial dilution contained no honey, but a small amount of glucose $(0.2 \mathrm{mg}$ per $100 \mathrm{ml}$ ) was present in the BHI broth. This amount of glucose, considered to be minimal, is therefore also present in all the subsequent dilutions.

\subsection{Control}

A hypertonic solution with a carbohydrate composition similar to natural honey (National Honey Board, 1988; Anderson et al., 1973) was made up under sterile conditions. The various sugars were D-glucose
$(31 \% \mathrm{w} / \mathrm{w})$, D-fructose $(38.5 \% \mathrm{w} / \mathrm{w})$, maltose $(7.2 \% \mathrm{w} / \mathrm{w})$ and sucrose $(1.5 \% \mathrm{w} / \mathrm{w})$. When tested, this proved to be sterile and was therefore not subjected to gamma irradiation. This highly viscous solution was kept refrigerated at $4{ }^{\circ} \mathrm{C}$ when not in use. In this study, the control solutions were diluted and treated as described for the honey samples.

\subsection{Inoculum}

A C. albicans reference strain 3118 from the National Collection of Pathogenic Fungi (NCPF) at the Central Public Health Laboratory (London, England) was used in this study. An overnight culture in BHI broth was diluted until an optical density (OD) of 0.1 was obtained in a Beckman model DU 64 spectrophotometer, set at a wavelength of 500 nanometres (Beckman Instruments, Fullerton, USA). This corresponded to a growth of $1.7 \times 10^{6}$ colony forming units (cfu) per ml of broth.

One half (0.5) millilitre of this inoculum was added to $50 \mathrm{ml}$ of each honey and control dilution and mixed thoroughly. A $1 \mathrm{ml}$ aliquot was taken from each dilution and kept refrigerated at $4{ }^{\circ} \mathrm{C}$ until further use. These aliquots would serve as blank reference standards when setting the spectrophotometer for reading optical densities at a later stage. All control and honey dilutions were performed in duplicate. The raw undiluted honey was tested for the presence of hydrogen peroxide by means of a commercial test strip (Peroxid-Test, Merck, Darmstadt, Germany).

The inoculated honey and control dilutions were placed in a shaking water bath (Haake model SWB 20, Haake Industries, Berlin, Germany), with the temperature set at $37{ }^{\circ} \mathrm{C}$ and the shaker at 60 revolutions per minute. After 24 hours of incubation, $1 \mathrm{ml}$ of each dilution was taken and the OD was read in the spectrophotometer, using the unincubated aliquots as a zero baseline reference standard. The OD of each honey 


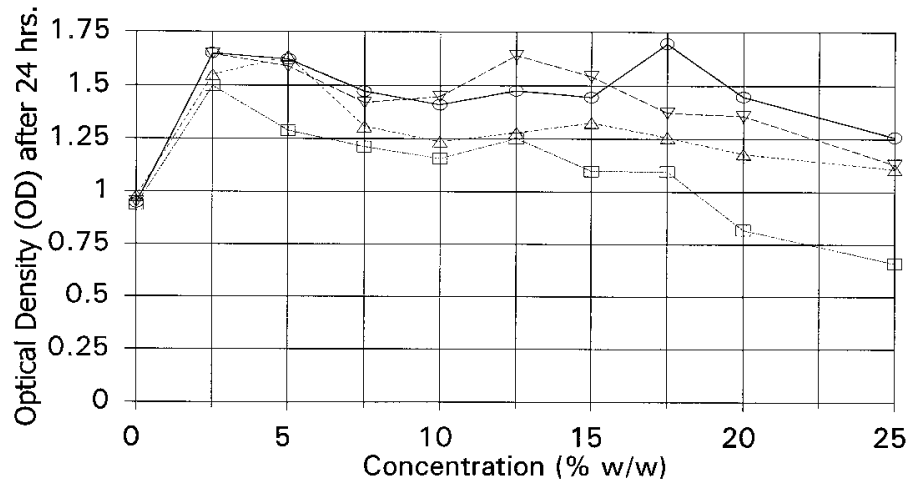

- control $\quad--\nabla$ fynbos $\quad \cdots \leftrightarrow$ bluegum $\quad \square$ wasbessie
Figure 1. The antifungal activity of different types of South African honey against $C$. albicans. and control solution was recorded on a graph (Fig. 1), while the variance of each set of readings was calculated.

\section{RESULTS}

Figure 1 illustrates the stimulation and inhibition on the growth of $C$. albicans in the 3 different honey samples tested, after 24 hours of incubation. The $\mathrm{x}$-axis represents the various honey concentrations ranging from 0 to $25 \%$ (w/w), while the y-axis shows the resultant optical density (OD) of each concentration tested. Stimulation in the growth of $C$. albicans was considered to have taken place when the OD showed an increase from one concentration to the next. Any reduction in the OD from one concentration to the next was considered to be partial inhibition, while any OD less than that produced in the initial concentration of $0 \%$ was deemed inhibition. Total inhibition takes place at that concentration where the OD produced is equal, or less, than that of the unincubated sample.

In 8 of the 11 dilutions, the sugar control produced an OD higher than that found in the 3 honey samples tested. A distinct peak occurred in the curve of the sugar control at the concentration of $2.5 \%$. The dilutions between $2.5 \%$ and $15 \%$ showed some partial inhibition in the growth of C. albicans.

In the 3 honey samples tested a distinct peak, similar to the one observed in the sugar control, can be seen at $2.5 \%$ and $5 \%$. Honey concentrations tested above $5 \%$ resulted in partial inhibition on the growth of C. albicans. In the 3 honey samples, the greatest partial inhibition on the growth was observed in the wasbessie honey sample, followed by the bluegum and fynbos honey samples respectively. Wasbessie honey, at a concentration of $20 \%$ and higher, produced an OD lower than that observed in the initial dilution of $0 \%$ and was therefore the only honey type to produce an inhibitory effect on the growth of $C$. albicans. At $25 \%$, the highest concentration tested, the degree of inhibition found in the wasbessie honey was $29.4 \%$. None of the samples tested could produce total inhibition on the growth of C. albicans. No hydrogen peroxide was found in any of the 3 undiluted honey samples.

The variance, or degree of error, was calculated for the 4 sets of OD readings and found to be as follows: control $=0.043$; fynbos honey $=0.046$; bluegum honey $=0.034$ and wasbessie honey $=0.053$. Curves of the OD readings from the various types of honey were also compared statistically with the 
control by means of the Wilcoxon signed rank sum test. Two of the honey types tested were found to differ significantly from the control; they were bluegum honey $(p=0.011)$ and wasbessie honey $(p=0.008)$. The difference between the fynbos honey and the control was found to be statistically insignificant $(p=0.441)$. Amongst honey types, there was also a significant difference between the wasbessie and bluegum honey $(p=0.008)$ and wasbessie and fynbos honey $(p=0.008)$. The difference between fynbos and bluegum was less, but still significant $(p=0.015)$.

\section{DISCUSSION}

The resultant OD curve produced by the control solution reached a distinct peak at the concentration of $2.5 \%$, where the maximum growth was achieved. Some partial inhibition on the growth of $C$. albicans was observed in the control solution and is best demonstrated in the concentrations higher than $17.5 \%$, after which the OD gradually decreases. The most likely explanation is that the stimulatory effect of the increasing amounts of additional carbohydrates ceases to have any effect on the growth of $C$. albicans beyond a concentration of $17.5 \%$ and is overtaken by the inhibitory factors present in the hypertonic solution. It is the hypertonic conditions that cause plasmolysis of the microbial cell, growth inhibition and death (Jay, 1970). For this reason, high sugar concentrations are used as a preservative in the manufacture of fruit preserves, candies and condensed milk.

By examining the curves of the 3 honey samples in Figure 1, a distinct peak can be seen at the concentrations of $2.5 \%$ and $5 \%$. The additional carbohydrates, as in the sugar control, stimulated the growth of the C. albicans up to an optimal point. Above this concentration, the inhibitory factors present in the honey caused a partial inhibition on the growth of $C$. albicans. This is evident by the gradual decline in the OD curve. In the fynbos and wasbessie honey, this occurred above a concentration of $12.5 \%$, while bluegum honey showed a gradual decline in the OD above the concentration of $15 \%$.

While it must be borne in mind that only a single sample from 3 different types of honey were tested and could be described as unrepresentative, a clear pattern does emerge. After the initial peak in the curve of the control and the 3 honey samples, there is a gradual decrease in the OD to the highest concentration tested. The wasbessie honey sample proved to have the greatest inhibitory effect on the growth of C. albicans. This is also the only honey sample to produce an OD lower than that of the initial concentration of $0 \%$, which contained no honey. In terms of our definition of inhibition, wasbessie honey at a concentration of $20 \%$ or higher was thus the only sample in our study to have shown inhibition; this was calculated to be $29.4 \%$. The partial inhibitory effect on the growth of $C$. albicans produced by fynbos honey was greater than that demonstrated by the control, while bluegum honey's inhibitory effect was less than that found in the wasbessie honey. Total inhibition was deemed to have taken place when the OD in any concentration was equal or lower, after incubation, than that recorded in the unincubated sample. None of the samples tested in this study displayed total inhibition.

Molan and Allen (1996) studied the possible effects of gamma irradiation on the antibacterial activity of 5 different types of New Zealand honeys against Staphylococcus aureus. After gamma irradiation of the samples at 25 and 50 kilograys, no significant difference could be found in the antibacterial activity of the honey tested. Since the honey samples in the present study were also irradiated, it was accepted that the antibacterial activity of the South African honeys remained unchanged.

One may conclude that the non-carbohydrate factors present in the 3 honey 
samples (such as plant-derived flavonoids, $\mathrm{pH}$ and buffering capacity) produced additional inhibition when compared with the control. The initial and rapid rise in the OD curve from the concentration of $0 \%$ to $5 \%$ may be attributed to the additional nutrients available in the honey, such as carbohydrates, minerals and vitamins. Above the concentration of $5 \%$, the inhibitory factors in the honey become dominant and results in the gradual lowering of the OD curve. This means that the growth benefits of the additional nutrients were masked by the inhibitory factors of honey at higher concentrations.

The various degrees of inhibition demonstrated in this study is most likely due to factors present in the different plant species from which the honey is collected, since the same bee species (Apis mellifera) was responsible for all the nectar collection. It could not be attributed to the water collected by the bees, since Du Toit et al. (1995) concluded that the elemental composition of water did not contribute substantially towards the levels of calcium, phosphorous or fluoride of honey. In a study by Allen et al. (1991) in which the antibacterial activity of honey from 26 different floral sources was tested on S. aureus, it was found that the difference between floral sources were high.

It is still unknown what the effect of honey would be on the many other microbial species found in the human oral cavity. Marsh and Martin (1998) listed more than 80 such microbes.

C. albicans is mainly associated with oral candidiasis; in patients with impaired immunity, neonates or the elderly. Other clinical conditions associated with $C$. albicans are vaginitis, otitis externa and chronic skin and mucous membrane infections (Shanson, 1989).

In a review by Molan on the antimicrobial activity of honey (1992), the findings of several workers are discussed. Cavanagh, Beazley and Ostapowicz (1970) found that a $100 \%$ (v/v) concentration of honey had a complete fungicidal effect on $C$. albicans, while a $50 \%$ concentration was necessary to bring about the same action in the species of C. stellatoidea, C. reukaufii and C. tropicalis. However, only a $10 \%(\mathrm{v} / \mathrm{v})$ honey concentration was necessary for a fungicidal effect against $C$. pseudotropicalis. In our study, we did not test whether the inhibitory effect was fungicidal and is therefore unable to make comparisons to these findings.

In the study of Dolezal, Dolezal and Medrela-Kuder (1988), it was found that a low honey concentration of $1.6 \%$ (v/v) could bring about complete inhibition of C. albicans. This was inconsistent with our findings and those of Revathy and Banerji (1980), who found that a $100 \%(\mathrm{v} / \mathrm{v})$ honey concentration caused complete inhibition. In our study, it was found that the wasbessie honey became inhibitory for $C$. albicans at a concentration of $20 \%(\mathrm{w} / \mathrm{w})$ or higher.

It may be deduced from the literature and the results of this study that various types of honey, at different concentrations, have different antimicrobial effects on various microbial species. Molan (1992) also reported that the antimicrobial activity of honey, within the same floral source, may be significantly different. After testing the 3 single samples of South African honeys, the conclusion is made that wasbessie honey was the only type that could produce inhibition on the growth of Candida albicans. At $25 \%(\mathrm{w} / \mathrm{w})$, the highest concentration tested, this inhibition was found to be $29.4 \%$. Bluegum and fynbos honey could only produce a partial inhibition on the growth of Candida albicans; the weakest antifungal action was seen in the fynbos honey.

Résumé - Action antifongique de trois miels d'Afrique du Sud vis-à-vis de Candida albicans. On sait peu de chose concernant l'action du miel sur la microflore orale. Les données connues laissent penser que 
l'action antibactérienne du miel est largement due aux effets osmotiques de la teneur hypertonique en sucres, au faible $\mathrm{pH}$ du miel et à la présence occasionnelle de péroxyde d'hydrogène.

Le but de l'étude était de déterminer les effets antifongiques contre un champignon commun de la cavité buccale saine, Candida albicans, de trois échantillons de miels d'Afrique du Sud, à savoir : un miel de Myrica cordifolia (Myricaceae), un miel d'eucalyptus (Eucalyptus cladocalyx) et un miel de fynbos (formation végétale arbustive constituée de diverses bruyères principalement du genre Erica). Ce champignon est également présent dans de nombreuses parties du corps, dans les intestins, le vagin et l'oreille, sur la peau et dans les muqueuses. Chez les patients immuno-déprimés, les nouveaux nés ou les personnes âgées, $C$. albicans peut provoquer une candidose orale connue sous le nom de muguet.

Les échantillons de miel ont été prélevés dans des ruches de la région de Western Cape en Afrique du Sud par des apiculteurs et envoyés au laboratoire. Tous les échantillons ont été irradiés aux rayons $\gamma$ à la dose de 20 kilograys pendant $10 \mathrm{~h}$ afin de les rendre stériles. Dans cette étude les dilutions ont été calculées sur une base poids par poids (w/w). Le poids spécifique a été déterminé pour chacun des miels : 1,455, 1,469 et 1,44 pour les miels d'eucalyptus, de fynbos et de $M$. cordifolia respectivement. Les diverses dilutions de miel, de 0 à $25 \%$ (w/w) ont été préparées dans $50 \mathrm{ml}$ d'un bouillon infusé cervelle-cœur. Ce bouillon a été inoculé avec $0,5 \mathrm{ml}$ d'une culture de nuit de $C$. albicans (souche de référence 3118 de la collection nationale de champignons pathogènes (NCPF) du « Central Public Health Laboratory » à Londres, Angleterre. Une solution hypertonique $(78 \% \mathrm{w} / \mathrm{w})$ avec une teneur en sucres semblable à celle du miel a servi de témoin. Les suspensions inoculées ont été incubées à $37{ }^{\circ} \mathrm{C}$ dans bain marie agité durant $24 \mathrm{~h}$ à 60 tours/minute. Des échantillons de $1 \mathrm{ml}$ ont été prélevés et la densité optique (DO) mesurée à l'aide d'un spectrophotomètre réglé à la longueur d'ondes de 500 nanomètres. On a considéré qu'il y avait stimulation de la croissance lorsque la DO diminuait et inhibition totale si la DO de l'échantillon incubé était égale ou inférieure à celle trouvée avant l'incubation.

On a observé une stimulation de la croissance de $C$. albicans et divers degrés d'inhibition pour le témoin sucre et les trois échantillons de miel. La plus forte inhibition de croissance de $C$. albicans a été obtenue avec le miel de $M$. cordifolia, suivi par le miel d'eucalyptus et le miel de fynbos (Fig. 1). La courbe de DO pour le témoin sucre, les miels de fynbos et de $M$. cordifolia ont atteint un pic à la dilution de 2,5\%. Des concentrations plus fortes ont abouti à une certaine inhibition de la croissance de C. albicans. Le miel d'eucalyptus a provoqué une croissance maximale à la concentration de $5 \%$, après quoi une diminution graduelle de la DO a été observée. Le miel de $M$. cordifolia a provoqué une croissance maximale à la concentration de $2,5 \%$. À la concentration de $20 \%$ et plus, il était le seul miel à inhiber la croissance par rapport à la concentration $0 \%$. Les autres miels n'ont provoqué qu'une inhibition partielle.

\section{miel / propriété antifongique / propriété antibactérienne / microflore orale / Candida albicans}

\section{Zusammenfassung - Antifungizide} Wirkungen von drei südafrikanischen Honigen auf Candida albicans. Über die Wirkung von Honig auf Teile der Mikroflora des Mundraums ist wenig bekannt. Die bis jetzt bekannten Daten lassen vermuten, dass die antibakteriellen Wirkungen von Honig hauptsächlich auf osmotischen Effekten durch den hypertonischen Zuckergehalt, den niedrigen $\mathrm{pH}$ vom Honig und durch das manchmal auftretende Wasserstoffperoxid hervorgerufen werden.

In dieser Untersuchung sollte die antifungizide Wirkung von 3 Einzelproben von 
Südafrikanischen Honigen gegen häufig in gesunden Mundhöhlen vorkommende Mikroben (vor allem Candida albicans) bestimmt werden, und zwar von Honig von Myrica cordifolia (Myricaceae), vom Blauen Gummibaum Eucalyptus cladocalyx und von Fynbos, einer speziellen Pflanzengesellschaft von Heidekraut, hauptsächlich bestehend aus Erica Arten. Der Pilz C. albicans kommt auf fast allen Körperteilen vor, wie z.B. im Eingeweide, in der Vagina, im Ohr, auf der Haut und in Schleimhäuten. Bei Patienten mit Immunschwäche, bei Neugeborenen oder Älteren kann der Pilz eine Candidiasis, eine sogenannte Mundfäule verursachen.

Die Honigproben wurden von Völkern im westlichen Kapgebiet von Südafrika von Imkern gesammelt und an das Labor geschickt. Alle Honigproben wurden mit Gamma Strahlen mit einer Dosis von 20 Kilograys 10 Stunden lang bestrahlt, um sie zu sterilisieren. Die Verdünnungen wurden auf der Basis von Gewicht zu Gewicht (w/w) durchgeführt. Als spezifisches Gewicht der Honige vom Gummibaum, Fynbos und M. cordifolia wurde 1,455; 1,469 bzw. 1,44 bestimmt. Verschiedene Verdünnungsstufen des Honigs mit Konzentrationen von 0 bis $25 \%$ (w/w) wurden mit $50 \mathrm{ml}$ einer Gehirn/Herz - Infusionsbrühe (BHI broth, code CM 225, Oxoid, Basingstoke, UK) hergestellt. Diese wurde mit $0,5 \mathrm{ml}$ einer Übernachtkultur von $\mathrm{Can}$ dida albicans beimpft, und zwar mit einem Stamm mit der Referenznummer 3118 der Nationalsammlung von pathogenen Pilzen (NCPF) des „Central Public Health Labors in London England“. Eine hypertonische Lösung (78 \% w/w) aus Zuckern, deren Konzentration der des Honigs entspricht, diente als Kontrolle. Die beimpften Aufschwemmungen (Suspensionen) wurden bei $37^{\circ} \mathrm{C}$ in einem Wasserbad mit Schütteleinrichtung (Haake Modell SWB 20, Haake Industrie, Berlin Deutschland) mit 60 Hüben pro Minute für 24 Stunden inkubiert. Proben von $1 \mathrm{ml}$ wurden herausgenommen und die optische Dichte (OD) wurde in einem
Beckman Spektralphotometer (Modell DU64, Beckman Instruments, Fullerton, USA) bei einer Wellenlänge von 500 Nanometern gemessen.

Eine Stimulierung des Wachstums wurde angenommen, wenn eine erhöhte optische Dichte (OD) von einer Konzentrationsstufe zur nächsten gemessen wurde. Eine Teilhemmung fand statt, wenn die OD abnahm. Wir waren der Ansicht, dass eine vollständige Hemmung stattfand, wenn die OD der inkubierten Probe gleich oder geringer war als ohne Inkubation.

Die Zuckerkontrolle und die 3 Honigproben stimulierten alle das Wachstum von C. albicans. Außerdem wurden unterschiedliche Stufen der Hemmung beobachtet. Die stärkste Wachstumshemmung wurde beim Honig von M. cordifolia beobachtet, gefolgt vom Gummibaum- und Fynboshonig (Abb. 1). Die OD-Kurve der Zuckerkontrolle, des Fynboshonigs und des Honigs von $M$. cordifolia zeigte bei einer Verdünnung von 2,5\% ein Maximum. Zunehmende Honigkonzentrationen führten zu einer partiellen Hemmung des Pilzwachstums. Mit dem Honig des Gummibaums wurde das höchste Wachstum bei einer Konzentration von $5 \%$ erreicht, danach nahm die OD allmählich ab.

Bei 2,5\% Honig von M. cordifolia erreichte $\operatorname{der} C$. albicans seine maximale Wachstumsrate. Ab $20 \%$ und höher erwies sich der Honig von $M$. cordifolia als einziger Honig, der eine Hemmung des Pilzwachstums im Vergleich zu den Lösungen ohne Honig bewirkte. Die anderen Honige erzeugen nur eine Teilhemmung.

\section{Honig / antifungizide Wirkung / antimik- robielle Wirkung / orale Mikroflora / Candida albicans}

\section{REFERENCES}

Allen K.L., Molan P.C., Reid G.M. (1991) A survey of the antibacterial activity of some New Zealand honeys, J. Pharm. Pharmacol. 43, 817-822. 
Anderson R.H., Buys B., Johannesmeier M.F. (1973) Bee keeping in South Africa, Department of Agriculture, Bulletin No. 394, Pretoria, South Africa.

Armon P.J. (1980) The use of honey in the treatment of infected wounds, Trop. Doct. 10, 91.

Basson N.J., Du Toit I.J., Grobler S.R. (1994) Antibacterial action of honey on oral streptococci, J. Dent Assn. S. Af. 49, 339-341.

Cavanagh D., Beazley J., Ostapowicz F. (1970) Radical operation for carcinoma of the vulva: a new approach to wound healing, J. Obstet. Gynaecol. Brit. Commonw. 77, 1037-1040.

Dold H., Du D.H., Dziao S.T. (1937) Nachweis antibakterieller, hitze- und lichtempfindlicher Hemmungsstoffe (Inhibine) im Naturhonig Blutenhonig, Z. Hyg. Infektionskrankh. 120, 155-167.

Dolezal M., Dolezal M., Medrela-Kuder E. (1988) Research on inhibine effect of herb-honey, Acta Biol. Cracov. Ser. Bot. 30, 9-16.

Dustmann H. (1979) Antibacterial effect of honey, Apiacta 14, 7-11.

Du Toit I.J., Grobler S.R., Kotze V.W.T.J., Basson N.J. (1995) Fluoride, calcium and phosphorus levels in bee honey and water, S. Afr. J. Sci. 91, 391-392.

Efem S.E. (1988) Clinical observations on the wound healing properties of honey, Brit. J. Surg. 75 679-681.

Goulart F.S. (1979) First aid from the hive: how honey heals, Am. Bee J. 119, 792

Grobler S.R., Jenkins G.N., Kotze D. (1985) The effect of the composition and method of drinking of soft drinks on plaque pH, Brit. Dent. J. 158, 293-296.

Grobler SR., Senekal P.J.C., Kotze V.W.T.J. (1989) The degree of enamel erosion by 5 different kinds of fruit, Clin. Prev. Dent. 11, 23-28.

Grobler S.R., Du Toit I.J., Basson N.J. (1994) The effect of honey on human tooth enamel in vitro observed by electronmicroscopy and microhardness measurements, Arch. Oral. Biol. 39, 147-153.

Haffejee I.E., Moosa A. (1985) Honey in the treatment of infantile gastro-enteritis, Brit. Med. J. 290, 1866-1867.
Havsteen B. (1983) Flavonoids, a class of natural products of high pharmacological potency, Biochem. Pharmacol. 32, 1141-1148.

Ibrahim A.S. (1981) Antibacterial action of honey, Bull Islam. Med. 1, 363-365.

Jay J.M. (1970) Modern food microbiology, Van Nostrand Reinhold Company, New York, USA pp. 3-11.

Marsh P.D., Martin M. (1998) Oral Microbiology, Butterworth-Heinemann, Oxford, UK, 4th ed.

Molan P.C. (1992) The antibacterial activity of honey (part 1), Bee World 73, 5-28.

Molan P.C., Allen K.L. (1996) The effect of gammairradiation on the antibacterial activity of honey, J. Pharm. Pharmacol. 48, 1206-1209.

National Honey Board Honey, USA (1988) From natures food industry: Information brochure, p. 2.

Revathy V., Banerji S.A. (1980) A preliminary study of antibacterial properties of Indian honey, Indian J. Biochem. Biophys. 17, supplement No. 242, 62.

Root A.L., Root E.R. (1980) ABC and XYZ of bee culture: an encyclopaedia pertaining to scientific and practical culture of bees, Root Publishing Company, Ohio, USA, 38th ed.

Sela M.O., Shapira L., Grizim I., Lewinstein I., Steinberg D., Gedalia I., Grobler S.R. (1998) Effects of honey consumption on enamel microhardness in normal versus xerostomic patients, Oral. Rehab. $25,630-634$.

Shanson D.C. (1989) Microbiology in Clinical Practice, Wright, London, UK, 2nd ed.

Smith J.A., Ross W.D. (1910) Historia animalium. The works of Aristotle, Oxford University Press, Oxford, UK, Volume IV, Translation by Thompson DAW.

White JW., Subers M.H., Schepartz A.L. (1963) The identification of inhibine, the antibacterial factor in honey, as hydrogen peroxide and its origin in a honey glucose-oxidase system, Biochem. Biophys. Acta 73, 57-70.

White J.W. (1975) Composition of honey, in: Crane E. (Ed.), Honey: a comprehensive survey, Heinemann, London, UK. 